\title{
NHE1 is upregulated in gastric cancer and regulates gastric cancer cell proliferation, migration and invasion
}

\author{
RUI XIE ${ }^{1,2^{*}}$, HAIBO WANG ${ }^{1,2}$, HAI JIN ${ }^{1,2}$, GUORONG WEN ${ }^{1,2}$, BIGUANG TUO ${ }^{1,2}$ and JINGYU XU ${ }^{1-3^{*}}$ \\ ${ }^{1}$ Department of Gastroenterology, Affiliated Hospital, Zunyi Medical College, Zunyi, Guizhou 563003; \\ ${ }^{2}$ Digestive Disease Institute of Guizhou Province, Zunyi, Guizhou 563003; \\ ${ }^{3}$ Department of Physiology, Zunyi Medical College, Zunyi, Guizhou 563003, P.R. China
}

Received May 15, 2016; Accepted July 6, 2016

DOI: $10.3892 /$ or.2017.5386

\begin{abstract}
Na}^{+} / \mathrm{H}^{+}$exchanger isoform 1 (NHE1) is known to play a key role in regulating intracellular $\mathrm{pH}$ and osmotic homeostasis and is involved in the development and progression of several types of cancer. However, the function and specific mechanism of NHE1 in gastric cancer (GC) are not clearly understood. In the present study, we report that NHE1 is overexpressed in tissues and cell lines from GC patients, and knockdown or inhibition of NHE1 suppressed GC cell proliferation via regulation of $\mathrm{G} 1 / \mathrm{S}$ and $\mathrm{G} 2 / \mathrm{M}$ cell cycle phase transitions, concomitant with a marked decrease in positive cell cycle regulators, including cyclin D1 and cyclin B1. Likewise, NHE1 was required for GC cell migration and invasion through the regulation of epithelial-mesenchymal transition (EMT) proteins, and NHE1 inhibition resulted in an acidic intracellular environment, providing possible mechanisms underlying NHE1-mediated GC progression both in vitro and in vivo. These data highlight the important role of NHE1 in GC progression and suggest that NHE1 may be a useful target for GC therapy.
\end{abstract}

\section{Introduction}

Gastric cancer (GC) is one of the most commonly diagnosed cancers worldwide and is associated with a poor prognosis (1).

Correspondence to: Professor Biguang Tuo or Dr Jingyu Xu, Department of Gastroenterology, Affiliated Hospital, Zunyi Medical College, 149 Dalian Road, Zunyi, Guizhou 563003, P.R. China

E-mail: tuobiguang@aliyun.com

E-mail: xujingyu_gzzy@126.com

*Contributed equally

Abbreviations: $\mathrm{NHE} 1, \mathrm{Na}^{+} / \mathrm{H}^{+}$exchanger isoform $1, \mathrm{GC}$, gastric cancer, pHi, intracellular $\mathrm{pH}$; $\mathrm{pHe}$, extracellular $\mathrm{pH}$; EMT, epithelial-mesenchymal transition; BCECF-AM, 2',7'-bis-(2-carboxyethyl)-5-(and 6)-carboxyfluorescein, acetomethyl ester; MMPs, matrix metalloproteinases; EIPA, 5-N-ethyl-N-isopropylamiloride

Key words: $\mathrm{Na}^{+} / \mathrm{H}^{+}$exchanger isoform 1, gastric cancer, intracellular $\mathrm{pH}$, pathogenesis
Although there are several treatments for GC, including surgery, chemotherapy (2) and/or radiation therapy (3), GC is difficult to diagnose in early stages and therefore difficult to cure. Since GC is a molecular disease caused by the activation of oncogenes and/or inactivation of tumor-suppressor genes (such as other tumors) (4), it is beneficial to identify these important genes to develop efficient prevention and treatment strategies for GC.

Recent studies indicate that the acidic tumor microenvironment is closely related to the biological behavior of tumor cells $(5,6)$. The acidic extracellular environment and alkaline intracellular environment can promote the proliferation, invasion and metastasis of tumor cells by influencing cell metabolism and the activity of migration-associated genes $(6,7)$. Several pH-regulated genes (VATP-pase, SLC4A1/4 and NHE) are known to participate in the progression of tumors such as liver and breast cancer, and pancreatic carcinoma $(8,9) . \mathrm{Na}^{+} / \mathrm{H}^{+}$ exchanger isoform 1 (NHE1) is the most direct $\mathrm{pH}$ regulator and has become a focus of research in recent years (10). NHE1, the most abundant isoform of the NHE exchanger family, is a membrane protein that is present in many mammalian cell types, and is involved in regulating intracellular $\mathrm{pH}(\mathrm{pHi})$ and osmotic homeostasis (11). It has recognized functions in determining the pHi by catalyzing the electroneutral exchange of extracellular $\mathrm{Na}^{+}$and intracellular $\mathrm{H}^{+}$(12). Previous research has revealed that NHE1 not only contributes to heart disease and leukemia $(13,14)$, but is also an important promoter of cancer in the progression of breast cancer and human small cell lung cancer cells $(15,16)$. Our previous study demonstrated that the upregulation of NHE1 enabled liver cancer proliferation, migration and invasion (8).

Although the expression and function of NHE1 in the stomach have been demonstrated in healthy humans (17), the function and specific mechanism of NHE1 in digestive cancer, particularly GC, are not clearly understood.

In the present study, we showed that the expression of NHE1 was higher in GC tissues and cell lines than that noted in normal tissues and cell lines. Loss of function of NHE1 suppressed GC cell proliferation, migration and invasion in vitro, and NHE1 inhibition reduced GC tumor growth in nude mice. Moreover, NHE1 regulated these events through changes in the $\mathrm{pHi}$ and the expression of corresponding genes. Our findings suggest that modulation of NHE1 and its 
downstream signaling pathways could be a novel therapeutic strategy for human GC.

\section{Materials and methods}

Human specimens. Tissue samples were obtained under sterile conditions from 15 patients with primary GC who underwent surgery at the Department of Surgery, Affiliated Hospital of Zunyi Medical College (Zunyi, China). Samples from primary GC tissues and their normal paraneoplastic counterparts were shock frozen in liquid nitrogen and stored at $-80^{\circ} \mathrm{C}$. This study was approved by the Ethics Committee of the Hospital Affiliated to Zunyi Medical College and all patients provided written in form consent for the use of their samples.

Cell lines. GES-1, SGC-7901 and MKN-45 cells were obtained from the Chinese Academy of Sciences (Shanghai, China). GES-1 is an immortalized human gastric normal epithelial mucosa cell line and SGC-7901 and MKN-45 are human GC cell lines. These cells are commonly used in the study of GC. 5-N-ethyl-N-isopropylamiloride (EIPA) was purchased from Sigma (St. Louis, MO, USA). After dissolving EIPA in dimethyl sulfoxide (DMSO), it was diluted in cell culture media to final concentrations below $0.1 \%$.

Cell culture. GES-1, SGC-7901 and MKN-45 cells were maintained in RPMI-1640 and Iscove's Dulbecco's modified Eagle's medium (DMEM) (Gibco-BRL, Gaithersburg, MD, USA). All cells were grown in medium supplemented with $10 \%$ fetal calf serum (Gibco-BRL) in an incubator with $5 \% \mathrm{CO}_{2}$ at $37^{\circ} \mathrm{C}$. The cells were used for experiments after they reached $70-80 \%$ confluence.

Immunohistochemistry. Slides containing human GC tissues were incubated with an anti-NHE1 monoclonal antibody (1:100 dilution; Abcam, Cambridge, MA, USA). The primary antibodies were detected with biotinylated goat anti-mouse IgG (Vector Laboratories, Burlingame, CA, USA) secondary antibodies. Immunoreactivity was detected using a horseradish peroxidase (3,3'-diaminobenzidine) kit (BioGenex, San Francisco, CA, USA), followed by counterstaining with hematoxylin, dehydration and mounting. The slides were then examined with a Nikon Eclipse 800 Research microscope.

Immunofluorescence staining. The cells were cultured on $8 \times 8 \mathrm{~cm}$ coverslips and fixed with ice-cold methanol/acetone for $20 \mathrm{~min}$, then permeabilized [0.1\% Triton X-100 in phosphate-buffered saline (PBS)] for $25 \mathrm{~min}$, blocked for $30 \mathrm{~min}$ and incubated with primary antibodies against NHE1 (1:200 dilution; Abcam) overnight at $4^{\circ} \mathrm{C}$. The cells were subsequently incubated with a FITC-IgG fluorescent secondary antibody (1:500 dilution; ZSGB-BIO, Beijing, China) at $37^{\circ} \mathrm{C}$ for $1 \mathrm{~h}$. The cells were finally observed through an inverted fluorescence microscope (Olympus IX70; Olympus, Tokyo, Japan).

Measurement of acid secretion via digital pHi imaging. Cells were loaded with a $5 \mu \mathrm{mol} / 1$ concentration of the $\mathrm{pH}$-sensitive dye 2',7'-bis-(2-carboxyethyl)-5-(and 6)-carboxyfluorescein, acetomethyl ester (BCECF-AM) (Molecular Probes, Eugene, OR, USA) for $30 \mathrm{~min}$ in low-calcium HEPES-buffered Ringer's solution (125 mM NaCl, $5 \mathrm{mM} \mathrm{KCl,} 0.1 \mathrm{mM} \mathrm{CaCl}_{2}, 32.2 \mathrm{mM}$ HEPES and $5 \mathrm{mM}$ glucose, $\mathrm{pH}$ 7.4) at room temperature. After loading, the cells were excited at 490 and $440 \mathrm{~nm}$, and the emitted fluorescence was measured at $530 \mathrm{~nm}$. Real-time images were obtained using a Nikon Eclipse Ti epifluorescence microscope (x40 objective) and Easy Ratio Pro software (Photon Technology International). After the establishment of a stable baseline, the cells were exposed to the solution containing EIPA $(20 \mu \mathrm{mol} / \mathrm{l})$ or the control vehicle. After $30 \mathrm{~min}$, the cells were exposed to $10 \mathrm{mM} \mathrm{NH}_{4} \mathrm{Cl}$ for $4 \mathrm{~min}$. $\mathrm{pHi}$ was calculated on the basis of the fluorescence ratios from an intracellular calibration curve constructed at the end of each experiment using the nigericin/high- $\mathrm{K}^{+}$technique and a linear conversion formula. The $\mathrm{pHi}$ recovery rate was determined on the basis of the slopes of the linear regression lines of measurements obtained during the first $3 \mathrm{~min}$ of recovery after the removal of $\mathrm{NH}_{4} \mathrm{Cl}$ and was expressed as $\mathrm{pH}$ units/min.

Quantitative real-time PCR. Total RNA was extracted with RNAiso Plus. The RNA was reverse transcribed to cDNA using PrimeScript RT-polymerase (Takara, Tokyo, Japan). Quantitative PCR was performed using cDNA primers specific for NHE1. The GAPDH gene was used as an internal control. The real-time RT-PCR assays were performed using SYBR-Green SuperMix (Bio-Rad, Hercules, CA, USA). The qPCR primer pair for NHE1 was designed by RiboBio (Guangzhou, China). The primers were as follows: GAPDH forward, 5-CAGGAGGCATTGCTGATGAT-3 and reverse, 5-GAAGGCTGGGGCTCATTT-3; NHE1 forward, 5-CTC ATCTGTGCCTGTCTGTCC and reverse, 5-TCTGATGTCA CAGTCTTCGAGCAA-3.

Western blotting. Cells were lysed with lysis buffer [50 mM Tris (pH 7.4), $150 \mathrm{mM} \mathrm{NaCl}, 1 \%$ Triton $\mathrm{X}-100,1 \%$ sodium deoxycholate, $0.1 \%$ SDS and $5 \mathrm{mM}$ EDTA] and centrifuged at $12,000 \mathrm{x}$ g for $15 \mathrm{~min}$ to remove insoluble material. Protein contents were subsequently normalized. For immunoprecipitation analyses, the lysates were incubated with an NHE1 antibody for $1 \mathrm{~h}$ at $4^{\circ} \mathrm{C}$, followed by another $1 \mathrm{~h}$ incubation with protein A-agarose at $4^{\circ} \mathrm{C}$. Pellets or cell lysates were resuspended in $2 \mathrm{X}$ loading buffer, boiled for $5 \mathrm{~min}$, and separated via SDS-PAGE (10\%). Resolved proteins were transferred to a PVDF membrane (Millipore Corporation, Billerica, MA, USA). The membranes were blocked with blocking buffer [1X Tris-buffered saline with Tween-20 (TBST) with 5\% non-fat dry milk], followed by incubation with monoclonal antibodies against NHE1 (1:1,000; Abcam), GAPDH (1:5,000; Ambion, Thermo Fisher Scientific, USA), cyclin D1 (1:1,000), cyclin B1 $(1: 2,000)$, E-cadherin $(1: 1,000)$ and vimentin $(1: 3,000)$ (all from Abcam). After washing with TBST, the secondary antibody was applied. The signals were visualized using enhanced chemiluminescence (ECL; Thermo Fisher Scientific, Inc., Waltham, MA, USA) and recorded on a Gel Doc 2000 imaging scanner (Bio-Rad).

Cell proliferation assay. Cells were plated in 96-well culture dishes at $2 \times 10^{3}$ cells/well using DMEM with 5\% fetal bovine serum (FBS) as the culture medium. The cells were transfected with NHE1 shRNA or treated for $72 \mathrm{~h}$ with different doses of EIPA $(5,10,20$ or $30 \mu \mathrm{mol} / \mathrm{l})$. Cell viability was assessed with 
a Cell Counting Kit-8 (CCK-8) (Tongren, Shanghai, China). The CCK- 8 reagent was added to each well at $0.5-2 \mathrm{~h}$ before the endpoint of incubation. The optical density (OD) at $450 \mathrm{~nm}$ was determined for each well using a microplate reader. Experiments were repeated at least three times, in triplicate each time. Extinction measurements were calculated relative to the negative control at the corresponding time points.

Cell scratch test. Cells from each group were seeded into 24-well tissue culture plates at a density that reached $80 \%$ confluence as a monolayer at $24 \mathrm{~h}$. The monolayer was gently scratched across the center of the well with a $10-\mu 1$ pipette tip. After scratching, the well was gently washed with medium to remove the detached cells. After treatment with EIPA (20 $\mu \mathrm{mol} / \mathrm{l})$ or transfection with NHE1 shRNA, images were obtained at 0 and $24 \mathrm{~h}$ using a microscope. Narrower widths indicate the migration distance. In each group, at least three parallel wells were utilized for testing.

Transwell invasion assays. A 24-well Transwell chamber (8- $\mu \mathrm{m}$ pores; Corning, Corning, NY, USA) was used to evaluate the motility and invasive ability of SGC-7901 or MKN-45 cells exposed to different treatments. The upper surface of a polycarbonate filter with $8-\mu \mathrm{m}$ pores was coated with $100 \mu \mathrm{g}$ of Matrigel (Collaborative Biomedical, Bedford, MA, USA). The cells were suspended in serum-free RPMI-1640/DMEM $\left(1 \times 10^{4}\right.$ cells $\left./ 100 \mu \mathrm{l}\right)$, and the cells in the upper chambers were then transfected with NHE1 shRNA or treated with EIPA $(20 \mu \mathrm{mol} / \mathrm{l})$. The lower chambers were filled with $500 \mu \mathrm{l}$ of RPMI-1640 (10\% FBS) medium. After $24 \mathrm{~h}$ of incubation, the cells remaining on the upper surface of the filters were removed by wiping with cotton swabs, and the cells that had migrated onto the lower surface were stained with crystal violet. The number of cells on the lower surface of the filters was counted under a microscope at a magnification of x200 (Olympus Corporation, Tokyo, Japan), and the average number of cells in three random selected fields was taken as the number of cells exhibiting invasion. The experiments were performed in triplicate, and each sample was assayed in triplicate.

Treatment of subcutaneous (s.c.) GC xenografts. All animal experiments described in the present study conformed to the Guidelines of the Animal Care and Use Committee of Zunyi Medical College. Male nude mice ( 4-weeks old) were purchased from Hua Fu Kang (Beijing, China). Approximately $1 \times 10^{6}$ SGC-7901 cells from each group were injected into the armpits of the nude mice. When the tumors reached an average volume of $\sim 1 \mathrm{~mm}^{3}$, EIPA $(30 \mu \mathrm{mol} / \mathrm{l})$ was injected into the tumors in the armpits on one side once a day (100 $\mu \mathrm{l})$ and DMSO $(0.1 \%)$ was injected into the tumors in the armpits on the other side. The volume of the GC xenografts was assessed each week. Thirty days after the injection of tumor cells, using a digital caliper, the tumor volume (in $\mathrm{mm}^{3}$ ) was calculated using the formula: Volume $=(\text { length })^{2} \mathrm{x}$ width $/ 2$.

Cell cycle analysis. Cell cycle analysis was carried out using flow cytometry. Briefly, cells were fixed in $70 \%$ ethanol for $>18 \mathrm{~h}$ and incubated with RNase A $(0.2 \mathrm{mg} / \mathrm{ml})$ in PBS Propidium iodide was then added to the cell suspension.
Samples were analyzed by a FACSCalibur flow cytometer (Becton-Dickinson).

Statistical analysis. All data are expressed as means \pm SEM. Data were analyzed via one-way ANOVA followed by the Student-Newman-Keul post hoc test or Student's t-test for paired or unpaired samples with GraphPad Prism 5.0 (GraphPad, San Diego, CA, USA). P<0.05 was considered to indicate a statistically significant result.

\section{Results}

Overexpression of NHE1 in human GC tissues and cells. NHE1 expression has been reported to be upregulated in human breast and prostate cancer $(8,18)$. To study the potential role of NHE1 in GC, we first performed immunohistochemistry and western blotting to examine and compare NHE1 protein expression levels in 10 pairs of human GC tissues and their normal paraneoplastic counterparts. As shown in Fig. 1, NHE1 was detected in native human GC and normal tissues, but NHE1 expression was significantly upregulated in GC patient tissues compared with that in the normal tissues (Fig. 1A-D). Next, we performed qPCR to compare NHE1 transcripts levels, and the mRNA level of NHE1 in the GC patients was found to be 4.3-fold higher than that noted in the normal tissues (Fig. 1E). We also examined the expression of NHE1 in the human GC cell lines MKN-45 and SGC-7901 and the gastric normal epithelial mucosa cell line GES-1. Western blot and qPCR analyses revealed that the expression levels of both the NHE1 protein and transcript were upregulated in the SGC-7901 and MKN-45 cancer cells compared with these levels in the GES-1 cells (Fig. 1F and G). Finally, the immunofluorescence staining results showed that the NHE1 protein was predominately expressed in the plasma membrane and cytoplasm of the cells, and the intensity of immunofluorescence for endogenous NHE1 was significant increased in the GC cells (Fig. 1H). These results collectively demonstrated that NHE1 expression is upregulated in GC, implying a potential contributing role in $\mathrm{GC}$.

Inhibition of NHE1 suppresses the G1/S and G2/M cell cycle phase transition and proliferation in GC cells. The overexpression of NHE1 observed in the primary human GC resembled the expression profiles detected in breast and prostate cancer (8). We therefore hypothesized that in GC, NHE1 probably confers a growth advantage to the cancer cells. To evaluate this, we performed cell proliferation assays and found that EIPA (5, $10,20$ or $30 \mu \mathrm{mol} / \mathrm{l})$, a selective inhibitor of NHE1, suppressed the proliferation of MKN-45 and SGC-7901 cancer cells in a dose-dependent manner (Fig. 2A and B). To verify that NHE1 specifically mediates GC cell proliferation, an shRNA targeting NHE1 was constructed and successfully transfected into the GC cell lines MKN-45 and SGC-7901. Knockdown of NHE1 was found to significantly inhibit cell proliferation in the MKN-45 and SGC-7901 cancer cells (Fig. 2C and D). We next investigated the effect of NHE1 on the cell cycle distribution via flow cytometric analysis. Compared with the control (PBS) group, EIPA $(20 \mu \mathrm{mol} / \mathrm{l})$ treatment of the MKN-45 and SGC-7901 cells resulted in an increase in the proportion of cells in the G0/G1 and G2/M phases, but a reduction in the 

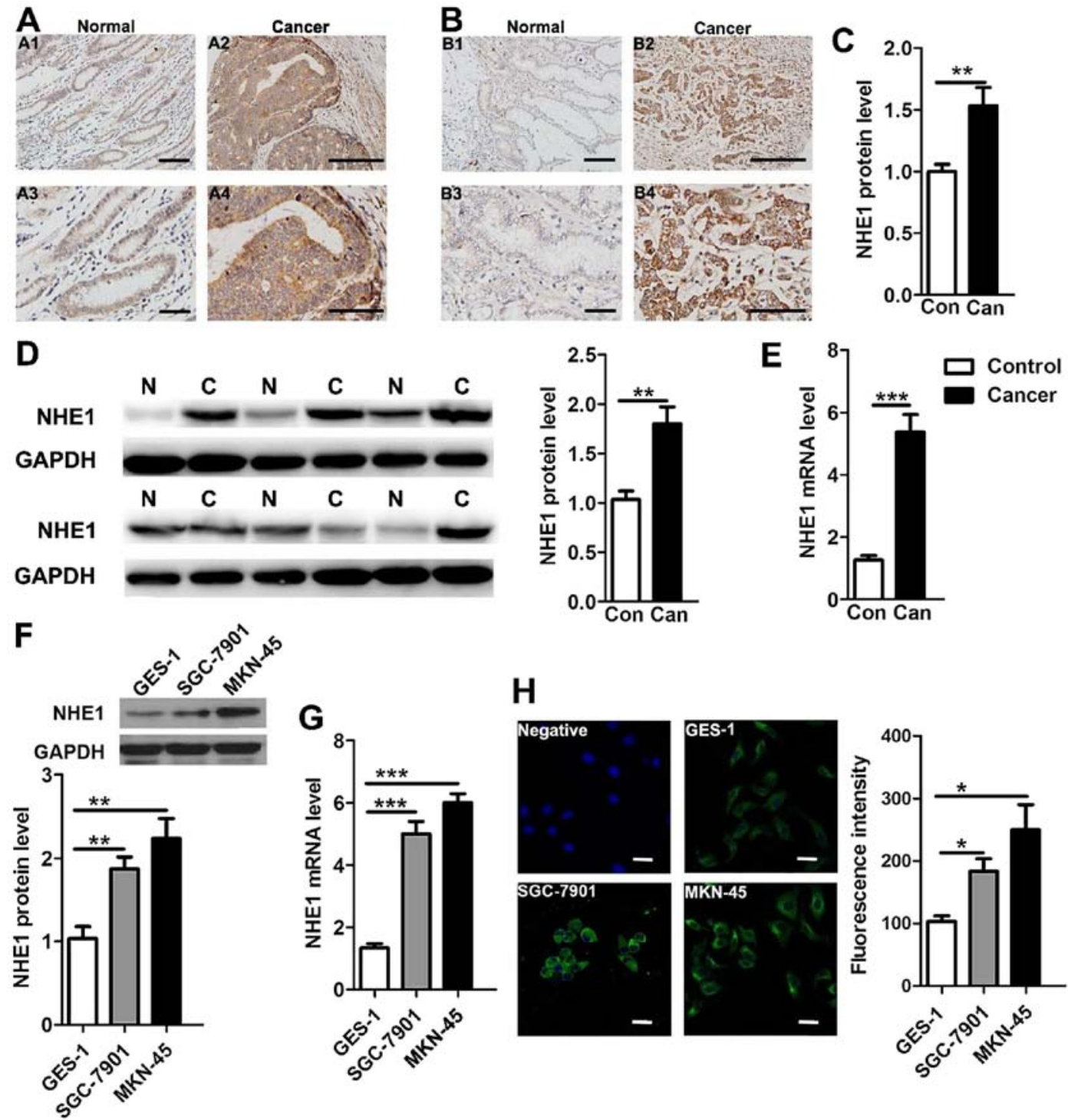

\section{H}
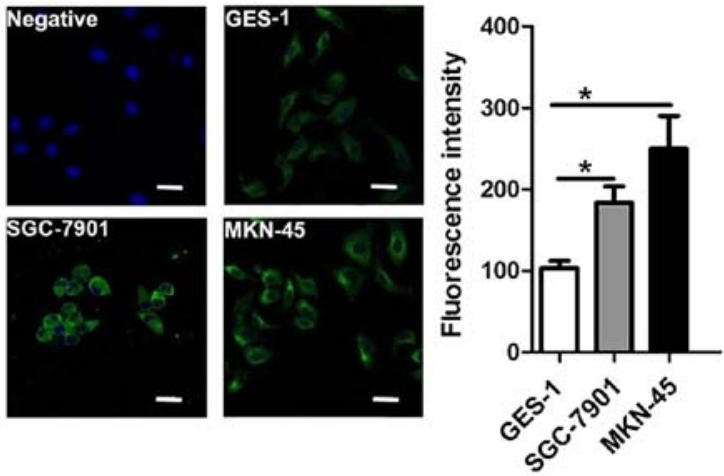

Figure 1. Enhanced expression of NHE1 in human gastric cancer (GC) tissues and cell lines. (A-C) Comparison of NHE1 protein expression through immunohistochemical analysis of human gastric cancer biopsy tissues (Can) and paraneoplastic normal tissues (Con) $\left({ }^{* *} \mathrm{P}<0.01, \mathrm{n}=10\right.$ pairs of samples for NHE1 expression analysis). The scale bars in A1, A3, B1 and B3 represent $50 \mu \mathrm{m}$. The scale bars in A2, A4, B2 and B4 represent $25 \mu \mathrm{m}$. (D) Western blot analysis of the NHE protein in human GC (C) (six samples shown) and normal (N) (six samples shown) tissues probed with anti-NHE1 (91 kDa) antibodies. GAPDH served as the protein loading control $\left({ }^{* *} \mathrm{P}<0.01, \mathrm{n}=15\right)$. (E) Histogram showing summary data on NHE1 mRNA expression in human gastric cancer biopsy tissues (Can) and paraneoplastic normal tissues (Con) $\left.{ }^{* * *} \mathrm{P}<0.001, \mathrm{n}=15\right)$. ( $\mathrm{F}$ and $\left.\mathrm{G}\right)$ Western blot and qPCR analyses of NHE1 protein and mRNA expression in a human normal gastric epithelial cell line (GES-1) and gastric cancer cell lines (SGC-7901 and MKN-45) $\left({ }^{* *} \mathrm{P}<0.01,{ }^{* * * *} \mathrm{P}<0.001 \mathrm{n}=3\right.$ independent experiments). (H) Representative immunofluorescence imaging of NHE1 protein staining in GES-1, SGC-7901 and MKN-45 cells and a negative control. The scale bar is $25 \mu \mathrm{m}\left({ }^{*} \mathrm{P}<0.05, \mathrm{n}=3\right.$ independent experiments).

proportion of cells in the S phase (Fig. 2E, F, I and J). Similarly, knockdown of NHE1 in the MKN-45 and SGC-7901 cells significantly increased the proportion of cells in both the $\mathrm{G} 0 /$ G1 and G2/M phases, which was associated with a decreased proportion of cells in the $\mathrm{S}$ phase (Fig. 2G-J). These data suggest that knockdown and inhibition of NHE1 suppressed GC cell proliferation via regulating cell cycle distribution.

Inhibition of NHE1 suppresses cell migration and invasion. To further investigate whether NHE1 upregulation is involved in the progression of GC, we performed assays to test cell migration and invasion. Wound-healing assays and Transwell experiments demonstrated that EIPA $(20 \mu \mathrm{mol} / \mathrm{l})$ prevented migration [MKN-45 control $(73.33 \pm 6.01 \mu \mathrm{m}) \mathrm{vs}$. EIPA $(32.67 \pm 5.01 \mu \mathrm{m})$; SGC-7901 control $(50.01 \pm 5.77 \mu \mathrm{m})$ vs. EIPA $(20.63 \pm 3.48 \mu \mathrm{m})]$ and invasion [MKN-45 control $(196 \pm 17)$ vs. EIPA $(50 \pm 11)$; SGC-7901 control (203 \pm 17$)$ vs. EIPA (56 \pm 5$)$ ] (Fig. 3A, B, E and F). Likewise, knockdown of NHE1 significantly inhibited cell migration [MKN-45 control $(60.13 \pm 5.77 \mu \mathrm{m})$ vs. EIPA $(36.61 \pm 4.41 \mu \mathrm{m})$; SGC-7901 control $(45.11 \pm 4.98 \mu \mathrm{m})$ vs. EIPA $(25.17 \pm 2.61 \mu \mathrm{m})]$ and invasion [MKN-45 control $(150 \pm 5)$ vs. EIPA (63 \pm 8$)$; SGC-7901

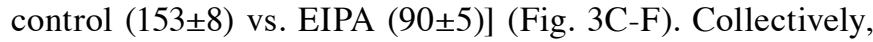
these data further support the hypothesis that NHE1 serves as a tumor promoter in human GC by inducing cell migration and invasion in vitro.

Enhanced NHE1 expression triggers an elevated pHi in GC cells. As a key pH regulator, NHE1 is known to maintain the pHi by exchanging one intracellular proton for one 

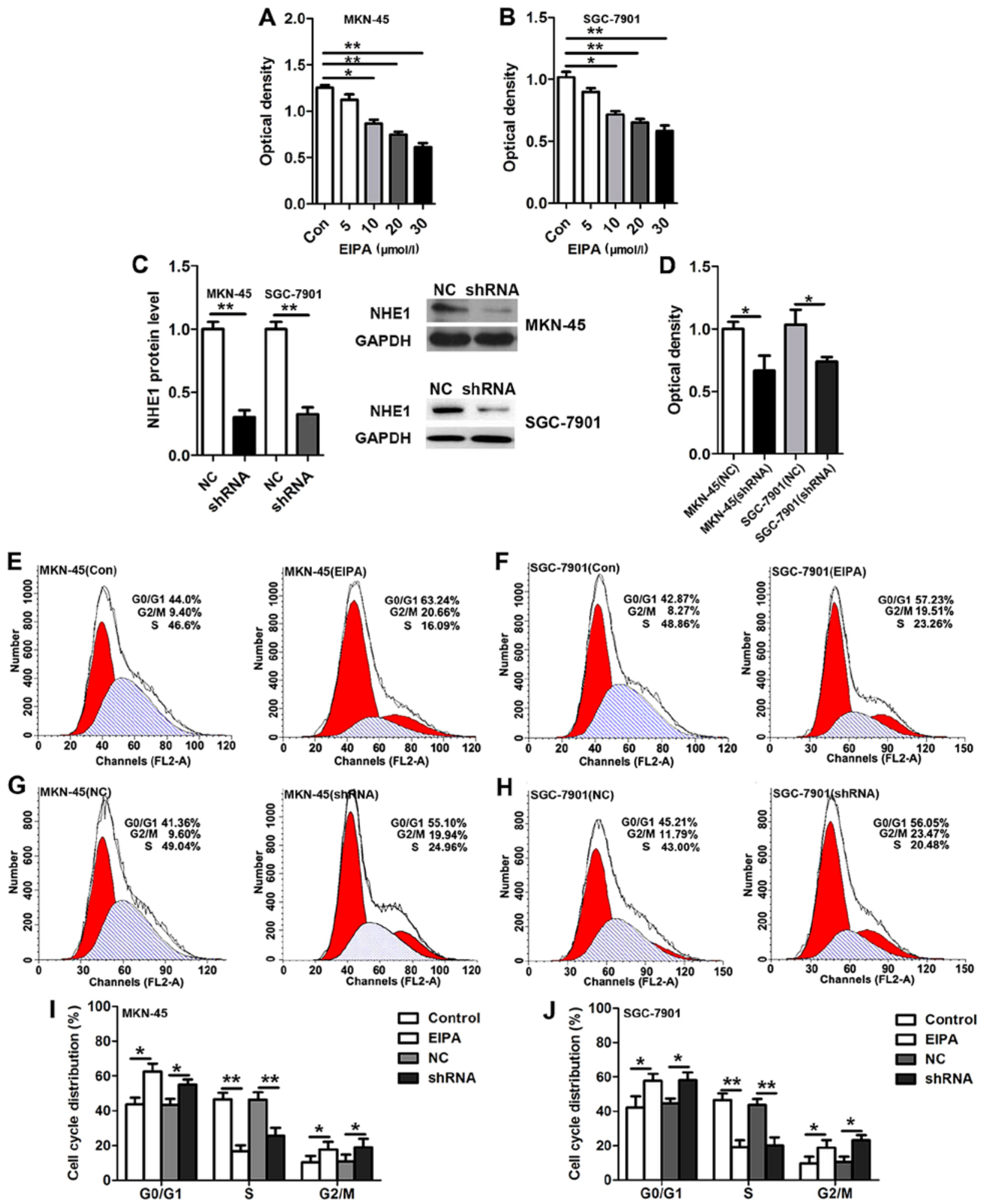

Figure 2. The role of NHE1 in the cell proliferation and cell cycle of gastric cancer in vitro. (A and B) Dose-dependent effects of EIPA (5, 10, 20 or 30 $\mu \mathrm{mol} / \mathrm{l})$ on MKN-45 and SGC-7901 cell proliferation as determined via the CCK-8 assay ( ${ }^{*} \mathrm{P}<0.05,{ }^{* *} \mathrm{P}<0.01, \mathrm{n}=3$ independent experiments). (C) Effect of shRNA knockdown on the protein expression of NHE1 in MKN-45 and SGC-7901 cells $\left({ }^{* *} \mathrm{P}<0.01, \mathrm{n}=3\right.$ independent experiments). (D) Effect of transfection with NHE1 shRNA and the negative control (NC) on MKN-45 and SGC-7901 cell proliferation ( $\mathrm{P}<0.05, \mathrm{n}=3$ independent experiments). (E and F) Flow cytometric analysis of the cell cycle in MKN-45 and SGC-7901 cells treated with EIPA $(20 \mu \mathrm{mol} / \mathrm{l})$ for $24 \mathrm{~h}$ (" $\mathrm{P}<0.05, \mathrm{n}=3$ independent experiments). (G and $\mathrm{H})$ Flow cytometric analysis of the cell cycle in MKN-45 and 7901 cells infected with NHE1 shRNA or NC. (I and J) Summary of cell cycle distribution in the SGC7901 and MKN-45 cell lines $\left({ }^{*} \mathrm{P}<0.05,{ }^{* *} \mathrm{P}<0.01, \mathrm{n}=3\right)$.

extracellular sodium and has been reported to be involved in the regulation of $\mathrm{pHi}$ in hepatocellular carcinoma and breast cancer development $(8,19,20)$. Inhibition of NHE1 function could decrease pHi to suppress cell proliferation and migration in these cancers. This hypothesis is consistent with the observation that analkaline intracellular environments 
A
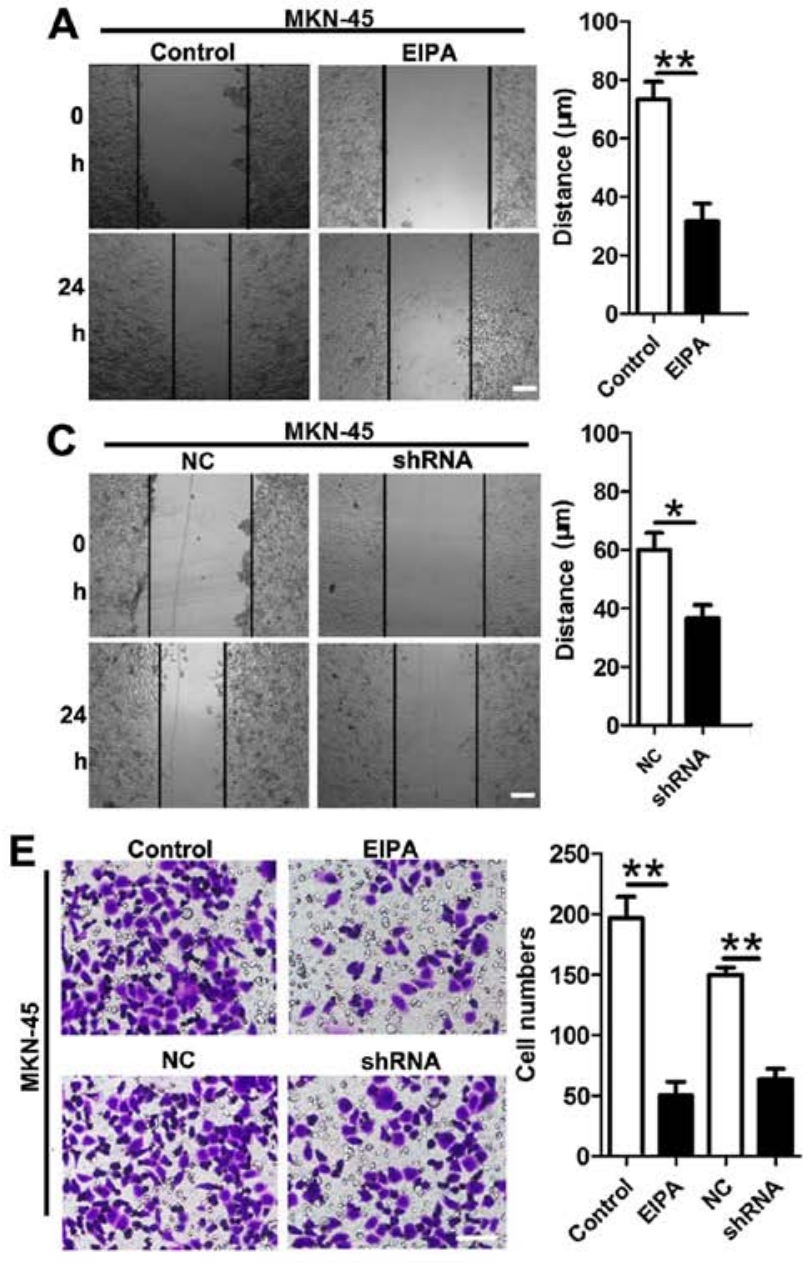

B
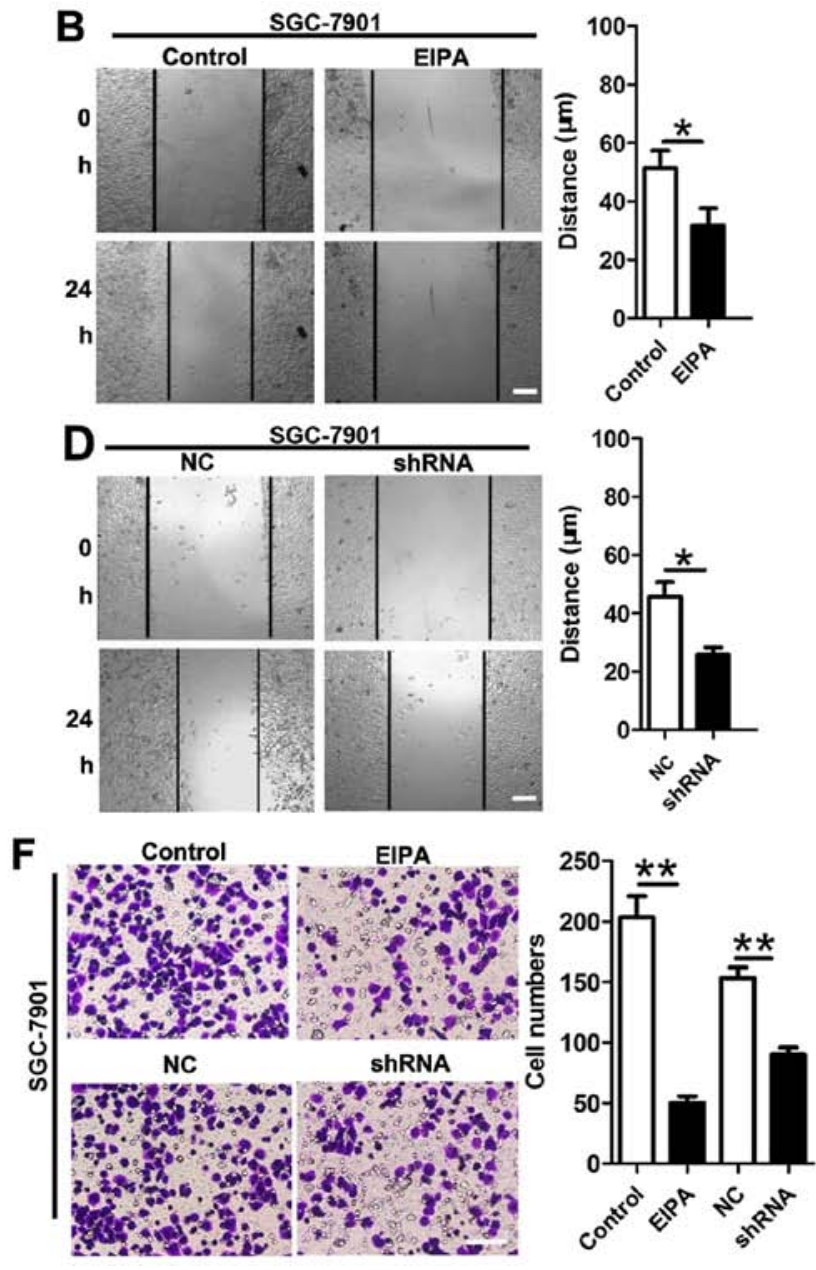

Figure 3. Tumorigenic role of NHE1 in the migration and invasion of gastric cancer in vitro. (A and B) Effects of EIPA (20 $\mu$ mol/l) on the migration capacity of MKN-45 and SGC-7901 cells as determined in cell scratch-wound assays $\left({ }^{*} \mathrm{P}<0.05,{ }^{* *} \mathrm{P}<0.01\right.$ vs. the controls, $\mathrm{n}=3$ independent experiments). The scale bars in each image represent $80 \mu \mathrm{m}$. (C and D) Effects of NHE1 knockdown on the migration capacity of MKN-45 and SGC-7901 cells as determined in cell scratchwound assays ( ${ }^{*} \mathrm{P}<0.05$ vs. the controls, $\mathrm{n}=3$ independent experiments). The scale bars in each image represent $80 \mu \mathrm{m}$. (E and F) Effects of EIPA and NHE1 knockdown on the invasion of MKN-45 and SGC-7901 cells as determined in Transwell experiments. The scale bars in each image represent $50 \mu \mathrm{m}\left({ }^{* *} \mathrm{P}<0.01\right.$ vs. the controls, $\mathrm{n}=3$ independent experiments).

are more suitable for cancer cell growth (21). Therefore, we hypothesized that the NHE1-mediated elevation of pHi could play a role in GC development. To test this hypothesis, we first examined the steady-state $\mathrm{pHi}$ and the recovery of $\mathrm{pHi}$ following acute intracellular acidification induced by $\mathrm{NH}_{4} \mathrm{Cl}$ in GES-1 (Fig. 4A), SGC-7901 (Fig. 4B) and MKN-45 cells (Fig. 4C). The $F(440) / F(495)$ ratio was converted to $\mathrm{pH}$ to obtain the intracellular proton concentration using the nigericin-based calibration technique, and the mean ratio values were plotted as a function of $\mathrm{pH}$ to produce a calibration curve (22). As shown in Fig. 4D, the steady-state pHi of the MKN-45 and SGC-7901 cancer cell lines was significantly increased compared with that of the GES-1 cell line. We next observed the recovery rate of pHi induced by NHE1 activation in the GES-1, SGC-7901 and MKN-45 cells. The $\mathrm{Na}^{+}$-dependent pHi recovery rate was faster in the $\mathrm{GC}$ cell lines than that noted in the normal cell line, as shown in Fig. 4E, which may be attributed to the enhanced expression or function of NHE1 in cancer tissues and cell lines, promoting the extrusion of intracellular proton $(\mathrm{H})$ ions. Furthermore, the NHE1 inhibitor EIPA $(20 \mu \mathrm{mol} / \mathrm{l})$ effectively reduced the steady-state $\mathrm{pHi}$ and the $\mathrm{pHi}$ recovery rate in both the SGC-7901 and MKN-45 cell lines (Fig. 4B, C, F and H). These effects may be attributed to the suppression of intracellular $\mathrm{H}^{+}$exchange with the extracellular environment by EIPA, followed by an increase in intracellular $\mathrm{H}^{+}$and reduction of pHi. The results of NHE1 knockdown showed the same effect as EIPA inhibition (Fig. 4G and I), indicating the specificity of NHE1-mediated pHi signaling. These results suggested that the regulation of $\mathrm{pHi}$ by $\mathrm{NHE} 1$ may contribute to $\mathrm{GC}$ development, and the decrease in pHi induced by NHE1 inhibition is a possible mechanism whereby NHE1 regulates GC progression.

NHE1 mediates GC progression by depressing the expression of cyclin proteins and epithelial-mesenchymal transition markers. We further aimed to identify the possible molecular mechanisms underlying the modulation of pHi by NHE1 in GC development. Since NHE1 regulates cell cycle distribution, we examined the expression of important cell cycle-related proteins after blocking the function and expression of NHE1. The NHE1 antagonist EIPA $(20 \mu \mathrm{mol} / \mathrm{l})$ reduced the expression of the 
A

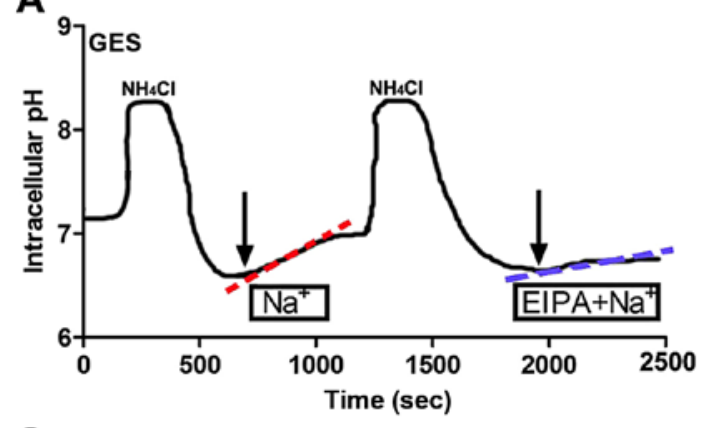

C

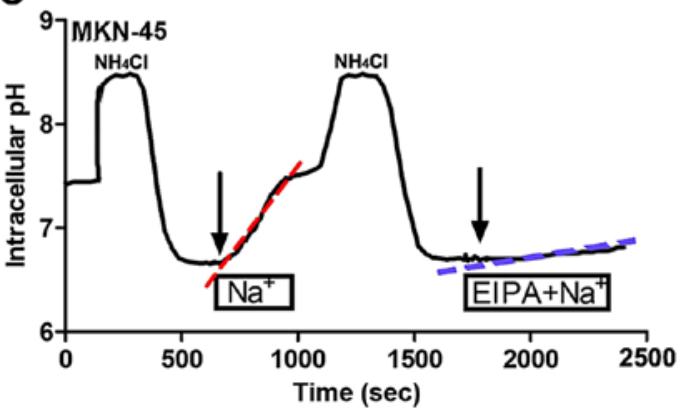

F

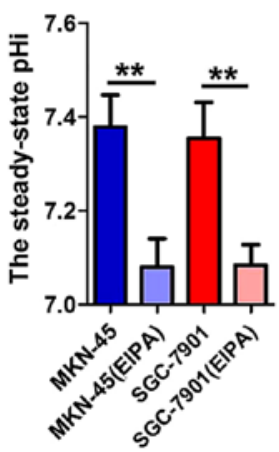

G

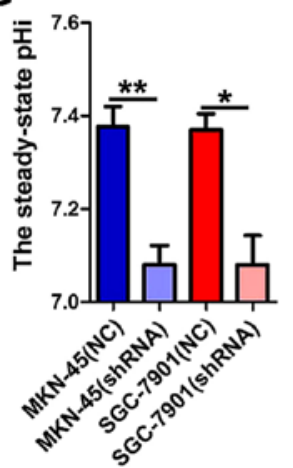

B

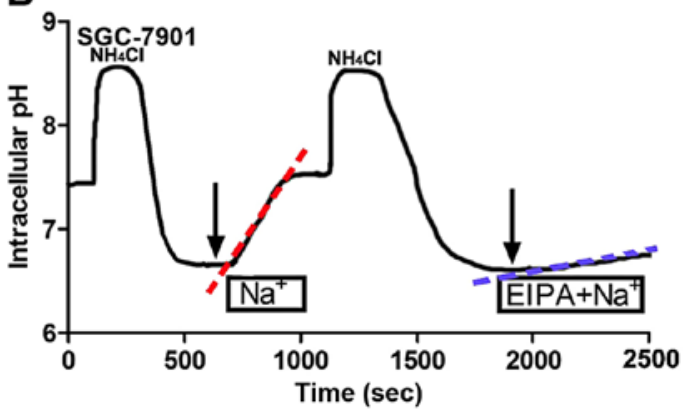

E
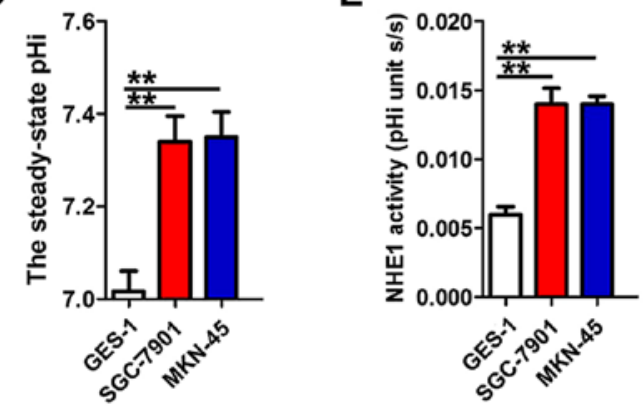

H
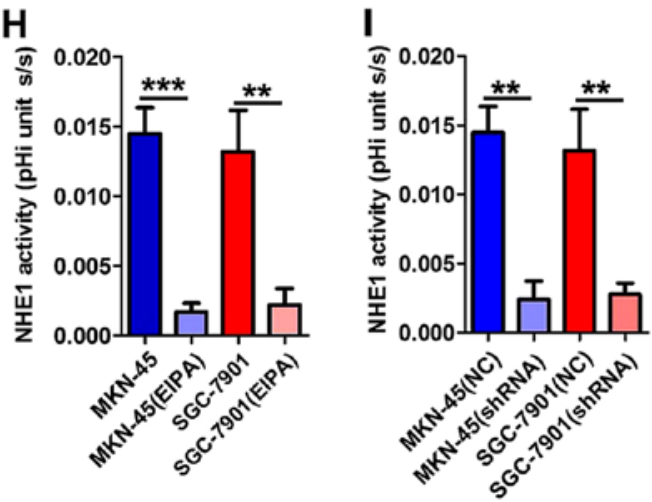

Figure 4. Original recordings of changes in intracellular proton concentrations in NHE1-overexpressing gastric cancer (GC) cells. (A-C) Original tracings of steady-state pHi and pHi recovery measurements in the absence and presence of $20 \mu \mathrm{mol} / 1$ EIPA in (A) GES-1, (B) SGC-7901 and (C) MKN-45 cells. (D) Summary of the steady-state pHi in the GES-1, SGC-7901 and MKN-45 cell lines ( ${ }^{* *} \mathrm{P}<0.01$ vs. the controls; $\mathrm{n}=23$ cell counts). (E) Summary of pHi recovery rates in the GES-1, SGC-7901 and MKN-45 cell lines ( ${ }^{* *} \mathrm{P}<0.01$ vs. the controls; $\mathrm{n}=26$ cell counts). (F and $\left.\mathrm{G}\right) \mathrm{Comparisons}$ of the steady-state pHi following treatment with EIPA or NHE1 knockdown in the MKN-45 and SGC-7901 cell lines $\left({ }^{*} \mathrm{P}<0.05\right.$, ${ }^{* *} \mathrm{P}<0.01$ vs. the controls; $\mathrm{n}=21$ cell counts). $(\mathrm{H}$ and $\mathrm{I})$ Comparison of the change of pHi recovery following treatment with EIPA or NHE1 knockdown in the MKN-45 and SGC-7901 cell lines $\left({ }^{* *} \mathrm{P}<0.01\right.$,

${ }^{* * * *} \mathrm{P}<0.001$ vs. the controls, $\mathrm{n}=21$ cell counts).

G1/S phase marker cyclin D1 as well as the G2/M phase marker cyclin B1 in the MKN-45 and SGC-7901 cells. Likewise, knockdown of NHE1 in the MKN-45 and 7901 cells also decreased the expression of cyclin D1 and cyclin B1 (Fig. 5A and B). It is suggested that NHE1 inhibition suppresses both the G1/S and the G2/M transitions in GC cells. Additionally, we examined some migration- and invasion-related genes. Studies have indicated that epithelial-mesenchymal transition (EMT) plays a critical role in the progression of various types of tumors (23), and we therefore analyzed the changes in the protein levels of E-cadherin and vimentin, two important markers of EMT. We found that EIPA $(20 \mu \mathrm{mol} / \mathrm{l})$ significantly decreased vimentin protein expression and enhanced E-cadherin protein expression in MKN-45 and SGC-7901 cells. Similar results were obtained following knockdown of NHE1 in the MKN-45 and SGC-7901 cells (Fig. 5C and D). The above results suggested that NHE1 mediates GC cell proliferation, migration and invasion via cyclin proteins and EMT markers.
Knockdown of NHE1 suppresses GC cell growth in nude mice. Finally, to obtain evidence that NHE1 is indeed important for the development of GC in vivo, we established a subcutaneously xenograft gastric tumor model in nude mice. On day 30 after the implantation of SGC-7901 cancer cells in the armpits on both sides of the mice (with or without EIPA injection), the NHE1 antagonist EIPA (30 $\mu \mathrm{mol} / \mathrm{l})$ significantly suppressed GC growth in the nude mice compared with the control groups (Fig. 6A-C).

\section{Discussion}

In the present study, we demonstrated that NHE1 serves as a key promoter in the development and progression of human gastric cancer (GC). Several lines of evidence support this hypothesis. First, enhanced expression of NHE1 was found not only in GC cell lines but also in human primary GC tissues compared with normal controls. Secondly, knockdown or inhi- 

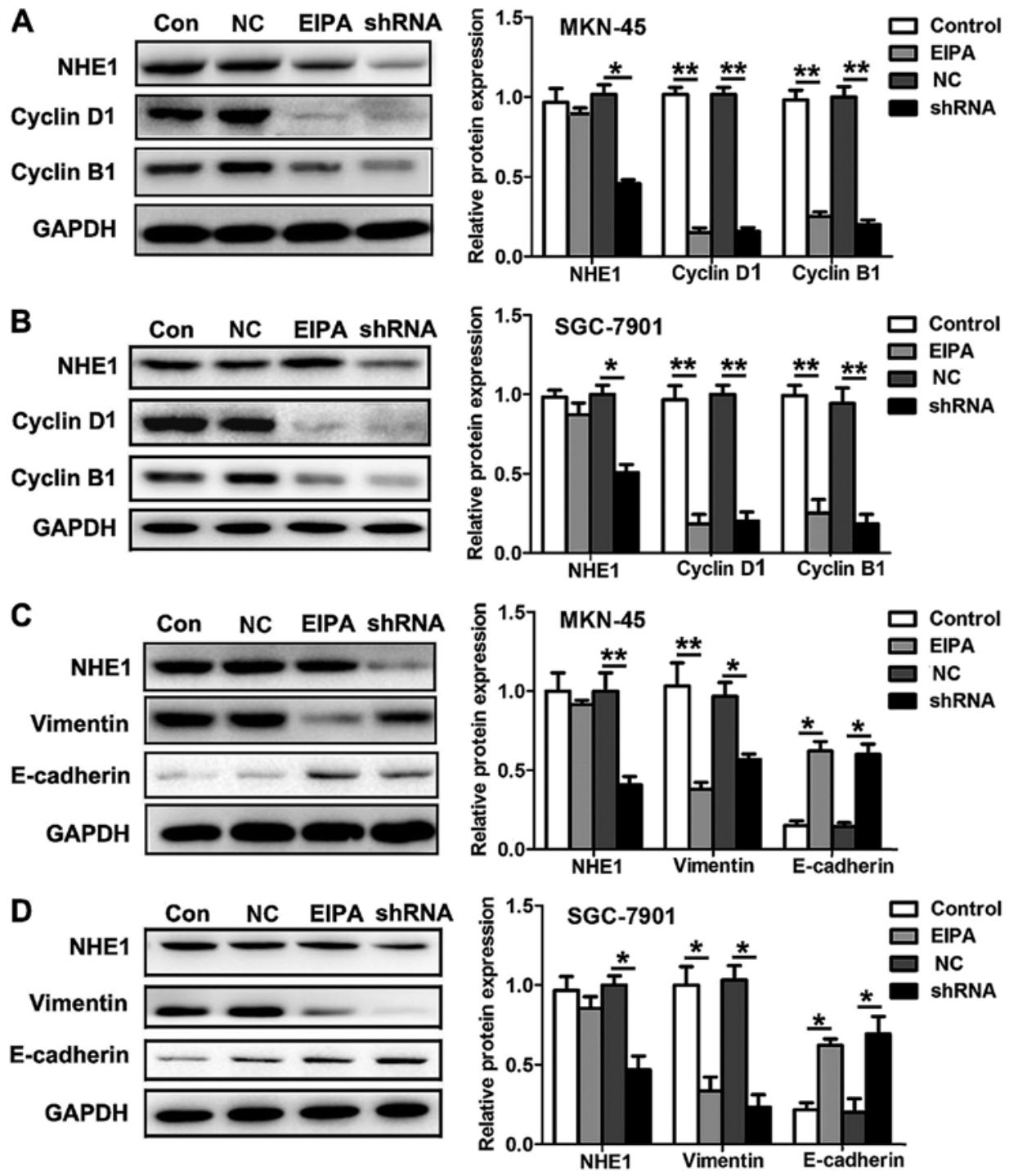

Figure 5. Suppressive effects of NHE1 expression on the cell cycle and EMT-related markers in gastric cancer (GC) cells. (A and B) Representative western blotting for the cyclin D1 and cyclin B1 proteins after treatment with EIPA $(20 \mu \mathrm{mol} / 1)$ and NHE1 knockdown in the MKN-45 and SGC-7901 cell lines $\left({ }^{*} \mathrm{P}<0.05,{ }^{* *} \mathrm{P}<0.01\right.$ vs. the controls; $\mathrm{n}=3$ independent experiments). (C and $\left.\mathrm{D}\right)$ Representative western blotting for the vimentin and $\mathrm{E}$-cadherin proteins after treatment with EIPA and NHE1 knockdown in the MKN-45 and SGC-7901 cell lines ( $\left(\mathrm{P}<0.05,{ }^{* *} \mathrm{P}<0.01\right.$ vs. the controls; $\mathrm{n}=3$ independent experiments).
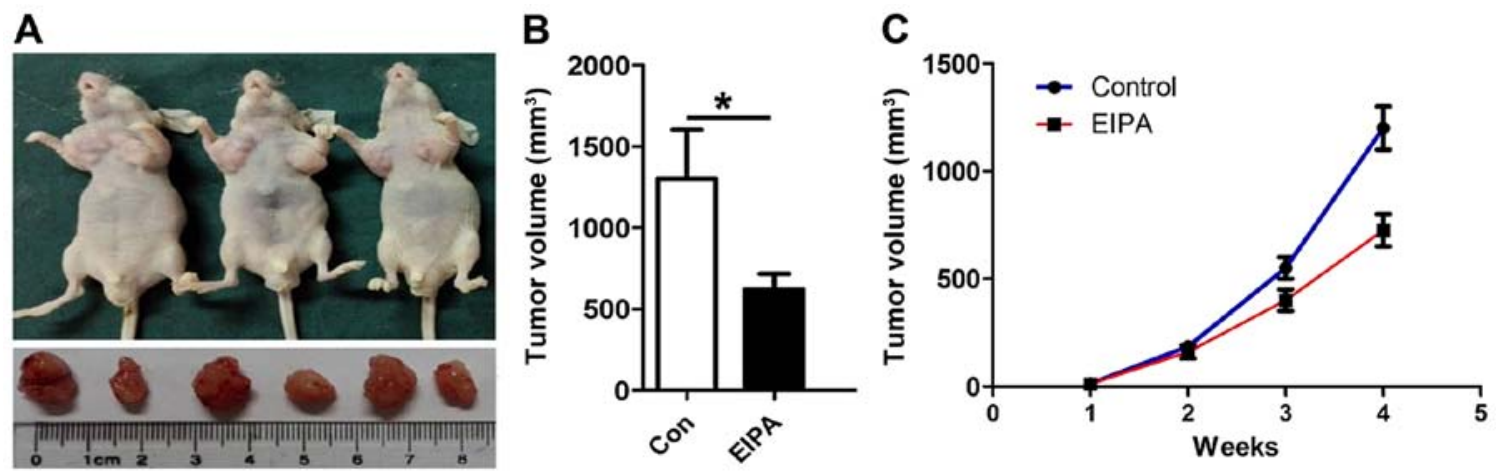

Figure 6. Tumorigenic role of NHE1 in the development of gastric cancer (GC) in vivo. (A) SGC-7901 cells were injected into the armpits of nude mice. Nude mice bearing subcutaneously xenografted tumors (with or without EIPA injection once a day) were sacrificed on day 30 after implantation. In each pair of tumors, the tumor on the right received EIPA injection, while the left side was injected with PBS. (B and C) Histograms and curves showing summary data for the xenografted tumor volumes with or without EIPA injection (control) $(\mathrm{P}<0.05, \mathrm{n}=3)$.

bition of NHE1 significantly suppressed GC cell proliferation, migration and invasion. Mechanistically, knockdown or inhi- bition of NHE1 reduced the steady-state pHi and the recovery rate of $\mathrm{pHi}$ in the SGC-7901 and MKN-45 cell lines, further 
regulating downstream cyclin proteins and EMT markers involved in GC progression. Finally, the NHE1 inhibitor EIPA suppressed GC cell growth in nude mice. These findings indicate that NHE1 may play an important role in the development and progression of GC.

Since the NHE1 isoform was cloned in 1989 by the Sardet group (24), nine mammalian isoforms belonging to the NHE family have been identified. NHE1 is an integral membrane protein consisting of 12 transmembrane segments (N-terminal) and a long cytoplasmic tail (C-terminal) that catalyzes the extrusion of intracellular proton $(\mathrm{H})$ ions in exchange for extracellular sodium $(\mathrm{Na})$ ions; the maintenance of this $\mathrm{pH}$ gradient from extracellular $\mathrm{pH}$ (pHe) to $\mathrm{pHi}$ is mainly due to NHE1 $(25,26)$. Physiologically, NHE1 activation promotes cell growth, differentiation, regulates sodium flux and the cell volume after osmotic shrinkage. In the field of cancer research, NHE1 has been shown to be overexpressed in breast cancer and cervical cancer, and increased NHE1 activity induced intracellular alkalization and promoted cell invasion $(8,27)$. Furthermore, decorin lowered NHE1 activity further inhibiting B16V melanoma cell migration and invasion by cellular acidification (28). Moreover, cisplatin-induced apoptosis was found to involve membrane fluidification via inhibition of NHE1 in human colon cancer cells (29). In the present study on gastric cancer (GC), we first examined the expression of NHE1 via immunohistochemistry and western blot analyses in 15 pairs of GC and normal samples. Enhanced expression of NHE1 was found in most of the GC samples compared with that noted in the matched normal tissues. Likewise, NHE1 protein and transcript levels were significantly upregulated in the GC cell lines, and knockdown or inhibition of NHE1 suppressed cell proliferation, the cell cycle, migration and invasion in GC cells both in vitro and in vivo. These finding suggest that NHE1 may play a key role in the advancement of human GC.

However, the understanding of the mechanisms underlying the role of NHE1 in GC remains insufficient. Both cell culture experiments and in situ tumor spectroscopic studies have shown that cancer cells exhibit quite a different acid-base balance from normal cells; tumor cells have alkaline pHi values of 7.12-7.7 vs. 6.99-7.05 in normal cells while producing acidic pHe values of 6.2-6.9 vs. 7.3-7.4 in normal cells. As known, the proteolytic breakdown of ECM proteins is one of the first steps in invasion in primary cancer lesions, and studies have confirmed that an acidic pHe can directly or indirectly drive ECM proteolysis and invasion by increasing protease production and the secretion of the active forms of cathepsin family members, serine proteases and matrix metalloproteinases (MMPs) (30-32). In addition, an increased $\mathrm{pHi}$ is necessary for actin polymerization. Alkaline pHi can stimulate cofilin activity and de novo actin polymerization to promote the leading edge membrane of migrating cells (33). Therefore, an alkaline pHi and acidic pHe not only increase cell metabolism but also contribute to the promotion of tumor cell invasion and migration. As an important $\mathrm{pH}$ regulator, NHE1 plays an essential role in the tumor microenvironment. Yang et al demonstrated that inhibition of NHE1 decreased pHi values and downregulated MMP-2, MMP-9 and VEGF expression to reduce hypoxiainduced hepatocellular carcinoma invasion and motility (34). NHE1 inhibitors are also reported to reduce the acidic tumor microenvironment, thereby rendering paclitaxel more effective in breast cancer chemotherapy (35). In the present study, we demonstrated that the MKN-45 and 7901 cancer cell lines exhibited a more alkaline pHi compared with the GES-1 cell line, and $\mathrm{Na}^{+}$-dependent $\mathrm{pHi}$ recovery was also faster in the GC cell lines than that noted in the normal cell line. These results may have attributed to the enhanced expression or function of NHE1 in cancer tissues and cell lines, promoting the extrusion of intracellular proton $(\mathrm{H})$ ions. Furthermore, the NHE1 inhibitor EIPA and treatment with shRNA targeting NHE1 effectively acidized pHi and suppressed pHi recovery in the MKN-45 and 7901 cells, indicating the specificity of NHE1-mediated pHi signaling in GC, and the suppression of invasion and migration in GC may be due to the inactivation of NHE1.

Abnormal regulation of the cell cycle is a marked characteristic of cancer cells, and dysregulation of the cell cycle by many tumor-suppressor genes and proto-oncogenes is essential for unlimited proliferation of cancer cells (36). It is known that cyclin D mediates the G1/S transition by binding to Cdk4. Cyclin D/Cdk4/6 phosphorylates $\mathrm{Rb}$, and $\mathrm{E} 2 \mathrm{~F}$ is then released to transactivate genes required for $\mathrm{G} 1 / \mathrm{S}$ transition. Furthermore, the G2/M DNA damage checkpoint prevents the cell from entering mitosis (M phase) if the genome is damaged, and the cyclin $\mathrm{B} / \mathrm{Cdk} 1$ complex plays an essential role in the regulation of the $\mathrm{G} 2 / \mathrm{M}$ checkpoint. Putney et al found that a transient increase in $\mathrm{pHi}$ induced by NHE1 promoted the timing of $\mathrm{G} 2 / \mathrm{M}$ in fibroblast cells $(37,38)$, but the relationship between NHE1 and the cyclin family in cancer cells is not clearly understood. In the present study, we showed that, in MKN-45 and SGC-7901 cells, knockdown or inhibition of NHE1 suppressed both G1/S and the G2/M phase transition, along with decreased expression of cyclin D1 and cyclin B1, suggesting that NHE1 is an important cell cycle regulator. EMT has been shown to play a critical role in the early stages of cancer metastasis (39). In order to investigate the mechanism whereby NHE1 regulates invasion and migration, we further examined the expression of various EMT markers. E-cadherin is well known to increase adhesion and repress migration/ invasion at EMT during cancer progression, and vimentin is a canonical marker of EMT whose pattern within the cell has important effects on the formation and function of invadopodia and lamellipodia during cellular invasion and migration (40). Downregulation of E-cadherin and upregulation of vimentin have been observed in several types of cancers, such as breast cancer, GC and colorectal cancers $(41,42)$ and TNF- $\alpha$ and VEGF can promote EMT by mediating E-cadherin and vimentin expression in human GC $(43,44)$. Our research also confirmed that ablation or inhibition of NHE1 significantly increased epithelial marker expression (E-cadherin) and decreased mesenchymal marker expression (vimentin) to suppress the invasion and migration of GC cells.

In conclusion, our data suggest that NHE1 is a key player in the development and progression of GC and that targeting of NHE1 is a promising therapeutic strategy against human GC.

\section{Acknowledgements}

The present study was supported by the National Natural Science Foundation of China (no. 81301731 and 81572438), The Program for Innovative Research Team in Guizhou Province 
(QKH-RCTD-20134035), and the Science and Technology Fund of Guizhou Province (JLKZI2011J46 and KHKHSZ201114).

\section{References}

1. Ang YL, Yong WP and Tan P: Translating gastric cancer genomics into targeted therapies. Crit Rev Oncol Hematol 100: 141-146, 2016.

2. Quéro L, Guillerm S and Hennequin C: Neoadjuvant or adjuvant therapy for gastric cancer. World J Gastrointest Oncol 7: 102-110, 2015.

3. Dehal A, Smith JJ and Nash GM: Cytoreductive surgery and intraperitoneal chemotherapy: An evidence-based review-past, present and future. J Gastrointest Oncol 7: 143-157, 2016.

4. Mattar R, Nonogaki S, Silva C, Alves V and Gama-Rodrigues JJ: $P 53$ and $R b$ tumor suppressor gene alterations in gastric cancer. Rev Hosp Clin Fac Med Sao Paulo 59: 172-180, 2004.

5. Kanamala M, Wilson WR, Yang M, Palmer BD and Wu Z: Mechanisms and biomaterials in $\mathrm{pH}$-responsive tumour targeted drug delivery: A review. Biomaterials 85: 152-167, 2016.

6. Parks SK, Cormerais Y, Marchiq I and Pouyssegur J: Hypoxia optimises tumour growth by controlling nutrient import and acidic metabolite export. Mol Aspects Med 47-48: 3-14, 2016.

7. Kato Y, Ozawa S, Miyamoto C, Maehata Y, Suzuki A, Maeda T and Baba Y: Acidic extracellular microenvironment and cancer. Cancer Cell Int 13: 89, 2013.

8. Amith SR and Fliegel L: Regulation of the $\mathrm{Na}^{+} / \mathrm{H}^{+}$Exchanger (NHE1) in Breast Cancer Metastasis. Cancer Res 73: 1259-1564, 2013.

9. Xu J, Ji B, Wen G, Yang Y, Jin H, Liu X, Xie R, Song W, Song P, Dong $\mathrm{H}$, et al: $\mathrm{Na}^{+} / \mathrm{H}^{+}$exchanger $1, \mathrm{Na}^{+} / \mathrm{Ca}^{2+}$ exchanger 1 and calmodulin complex regulates interleukin 6-mediated cellular behavior of human hepatocellular carcinoma. Carcinogenesis 37: 290-300, 2016.

10. Loo SY, Chang MK, Chua CS, Kumar AP, Pervaiz S and Clement MV: NHE-1: A promising target for novel anti-cancer therapeutics. Curr Pharm Des 18: 1372-1382, 2012.

11. Reshkin SJ, Cardone RA and Harguindey S: $\mathrm{Na}^{+}-\mathrm{H}^{+}$exchanger, $\mathrm{pH}$ regulation and cancer. Recent Patents Anticancer Drug Discov 8: 85-99, 2013.

12. Slepkov E and Fliegel L: Structure and function of the NHE1 isoform of the $\mathrm{Na}^{+} / \mathrm{H}^{+}$exchanger. Biochem Cell Biol 80: 499-508, 2002.

13. Odunewu-Aderibigbe A and Fliegel L: The $\mathrm{Na}^{+} / \mathrm{H}^{+}$exchanger and $\mathrm{pH}$ regulation in the heart. IUBMB Life 66: 679-685, 2014.

14. Garden OA, Musk P, Worthington-White DA, Dewey MJ and Rich IN: Silent polymorphisms within the coding region of human sodium/hydrogen exchanger isoform-1 cDNA in peripheral blood mononuclear cells of leukemia patients: A comparison with healthy controls. Cancer Genet Cytogenet 120: 37-43, 2000.

15. Amith SR, Wilkinson JM and Fliegel $\mathrm{L}$ : $\mathrm{Na}^{+} / \mathrm{H}^{+}$exchanger NHE1 regulation modulates metastatic potential and epithelial-mesenchymal transition of triple-negative breast cancer cells. Oncotarget 7: 21091-21113, 2016.

16. Li S, Bao P, Li Z, Ouyang H, Wu C and Qian G: Inhibition of proliferation and apoptosis induced by a $\mathrm{Na}^{+} / \mathrm{H}^{+}$exchanger- 1 (NHE-1) antisense gene on drug-resistant human small cell lung cancer cells. Oncol Rep 21: 1243-1249, 2009.

17. Konturek SJ, Konturek PC, Pawlik T, Sliwowski Z, Ochmański W and Hahn EG: Duodenal mucosal protection by bicarbonate secretion and its mechanisms. J Physiol Pharmacol 55 (Suppl 2): S5-S17, 2004.

18. Steffan JJ, Snider JL, Skalli O, Welbourne T and Cardelli JA: $\mathrm{Na}^{+} / \mathrm{H}^{+}$exchangers and $\mathrm{RhoA}$ regulate acidic extracellular $\mathrm{pH}$-induced lysosome trafficking in prostate cancer cells. Traffic 10: 737-753, 2009.

19. Fuster DG and Alexander RT: Traditional and emerging roles for the SLC9 $\mathrm{Na}^{+} / \mathrm{H}^{+}$exchangers. Pflugers Arch 466: 61-76, 2014

20. Amith SR and Fliegel L: Regulation of the $\mathrm{Na}^{+} / \mathrm{H}^{+}$exchanger (NHE1) in breast cancer metastasis. Cancer Res 73: 1259-1264, 2013.

21. Khajah MA, Almohri I, Mathew PM and Luqmani YA: Extracellular alkaline $\mathrm{pH}$ leads to increased metastatic potential of estrogen receptor silenced endocrine resistant breast cancer cells. PLoS One 8: e76327, 2013.
22. Boyarsky G, Hanssen C and Clyne LA: Inadequacy of high $\mathrm{K}+$ /nigericin for calibrating BCECF. II. Intracellular $\mathrm{pH}$ dependence of the correction. Am J Physiol 271: C1146-C1156, 1996.

23. Voulgari A and Pintzas A: Epithelial-mesenchymal transition in cancer metastasis: Mechanisms, markers and strategies to overcome drug resistance in the clinic. Biochim Biophys Acta 1796: 75-90, 2009.

24. Sardet C, Franchi A and Pouysségur J: Molecular cloning, primary structure, and expression of the human growth factor-activatable $\mathrm{Na}^{+} / \mathrm{H}^{+}$antiporter. Cell 56: 271-280, 1989.

25. Fliegel L: Molecular biology of the myocardial $\mathrm{Na}^{+} / \mathrm{H}^{+}$exchanger. J Mol Cell Cardiol 44: 228-237, 2008.

26. Kemp G, Young $\mathrm{H}$ and Fliegel L: Structure and function of the human $\mathrm{Na}^{+} / \mathrm{H}^{+}$exchanger isoform 1. Channels 2: 329-336, 2008.

27. Chiang Y, Chou CY, Hsu KF, Huang YF and Shen MR: EGF upregulates $\mathrm{Na}^{+} / \mathrm{H}^{+}$exchanger NHE1 by post-translational regulation that is important for cervical cancer cell invasiveness. J Cell Physiol 214: 810-819, 2008.

28. Stock C, Jungmann O and Seidler DG: Decorin and chondroitin-6 sulfate inhibit B16V melanoma cell migration and invasion by cellular acidification. J Cell Physiol 226: 2641-2650, 2011.

29. Rebillard A,Tekpli X, Meurette O,Sergent O,LeMoigne-MullerG, Vernhet L, Gorria M, Chevanne M, Christmann M, Kaina B, et al: Cisplatin-induced apoptosis involves membrane fluidification via inhibition of NHE1 in human colon cancer cells. Cancer Res 67: 7865-7874, 2007.

30. Jones EM, Cochrane CA and Percival SL: The effect of $\mathrm{pH}$ on the extracellular matrix and biofilms. Adv Wound Care 4: 431-439, 2015.

31. Turk B, Dolenc I, Lenarcic B, Krizaj I, Turk V, Bieth JG and Björk I: Acidic $\mathrm{pH}$ as a physiological regulator of human cathepsin L activity. Eur J Biochem 259: 926-932, 1999.

32. Greco MR, Antelmi E, Busco G, Guerra L, Rubino R, Casavola V, Reshkin SJ and Cardone RA: Protease activity at invadopodial focal digestive areas is dependent on NHE1-driven acidic pHe. Oncol Rep 31: 940-946, 2014

33. Yonezawa N, Nishida E and Sakai H: pH control of actin polymerization by cofilin. J Biol Chem 260: 14410-14412, 1985.

34. Yang $X$, Wang D, Dong W, Song $Z$ and Dou K: Inhibition of $\mathrm{Na}^{+} / \mathrm{H}^{+}$exchanger 1 by 5 -( $\mathrm{N}$-ethyl- $\mathrm{N}$-isopropyl) amiloride reduces hypoxia-induced hepatocellular carcinoma invasion and motility. Cancer Lett 295: 198-204, 2010.

35. Weaver BA: How Taxol/paclitaxel kills cancer cells. Mol Biol Cell 25: 2677-2681, 2014

36. Collins K, Jacks T and Pavletich NP: The cell cycle and cancer. Proc Natl Acad Sci USA 94: 2776-2778, 1997.

37. Santo L, Siu KT and Raje N: Targeting cyclin-dependent kinases and cell cycle progression in human cancers. Semin Oncol 42: 788-800, 2015

38. Putney LK, Denker SP and Barber DL: The changing face of the $\mathrm{Na}^{+} / \mathrm{H}^{+}$exchanger, NHE1: Structure, regulation, and cellular actions. Annu Rev Pharmacol Toxicol 42: 527-552, 2002.

39. Smith BN and Bhowmick NA: Role of EMT in metastasis and therapy resistance. J Clin Med 5: E17, 2016.

40. Ipekci T, Ozden F, Unal B, Saygin C, Uzunaslan D and Ates E: Epithelial-mesenchymal transition markers $\beta$-catenin, Snail, and E-cadherin do not predict disease free survival in prostate adenocarcinoma: A prospective study. Pathol Oncol Res 21: 1209-1216, 2015.

41. Yagasaki R, Noguchi M, Minami M and Earashi M: Clinical significance of E-cadherin and vimentin co-expression in breast cancer. Int J Oncol 9: 755-761, 1996.

42. Dorudi S, Sheffield JP, Poulsom R, Northover JM and Hart IR E-cadherin expression in colorectal cancer. An immunocytochemical and in situ hybridization study. Am J Pathol 142: 981-986, 1993.

43. Li K, Dan Z, Hu X, Gesang L, Ze Y and Bianba Z: CD14 regulates gastric cancer cell epithelial-mesenchymal transition and invasion in vitro. Oncol Rep 30: 2725-2732, 2013.

44. Zhou Y, Li G, Wu J, Zhang Z, Wu Z, Fan P, Hao T, Zhang X, Li M, Zhang F, et al: Clinicopathological significance of E-cadherin, VEGF, and MMPs in gastric cancer. Tumour Biol 31: 549-558, 2010. 